\title{
Physico-chemical properties and the microflora of moroccan black table olives
}

\author{
By A. Asehraou 1 , M. Faid ${ }^{*}$ and M. Jana 2. \\ 1. I.A.V. Hassan II Département de Microbiologie Alimentaire et Biotechnologie. BP 6202 Rabat-Institut. \\ MOROCCO. \\ 2. University Cadi ayad Faculté des Sciences. BP S15 Marrakech. MOROCCO. \\ * Author to whom correspondance should be addressed.
}

\section{RESUMEN}

Propiedades físico-químicas y microflora de aceitunas negras de mesa marroquíes.

Se estudiaron la microflora y las propiedades físico-quimicas de aceitunas negras de mesa en 11 muestras. Los microorganismos más abundantes contados incluyeron: flora mesofila total, indicadores de contaminación fecal (Coliformes totales y fecales, Enterococcus), Staphylococcus, Salmonella, esporulados (Bacillus y Clostridium) y levaduras y mohos. Los análisis físico-químicos incluyeron: aw (actividad de agua), $\mathrm{pH}$, índice de acidez de la materia grasa y concentración de $\mathrm{NaCl}$. Los resultados nos demuestran perfiles microbianos bajos para todos los microorganismos excepto levaduras y mohos. Los valores bajos de pH y de aw, y otros elevados del indice de acidez y del contenido en sal, nos sugiere una inhibición de estos factores sobre el crecimiento y/o la supervivencia de la microflora de las aceitunas negras de mesa.

PALABRAS-CLAVE: Aceituna negra de mesa - Marruecos - Microflora - Propiedades físico-químicas.

\section{SUMMARY}

Physico-chemical properties and the microflora of moroccan black table olives.

Eleven samples of Moroccan black table olives were analysed for their microflora and the physico-chemical factors. A survey of the most frequent microorganisms including standard plate count (SPC), counts of the indicator microorganisms (total and fecal coliforms and enterococci), staphylococci, Salmonella, sporeforming bacteria (Clostridium and BacilIus) and yeasts and molds was determined. The physico-chemical factors grouped $\mathrm{pH}, \mathrm{aw}, \mathrm{NaCl}$ concentration and the ADV (Acid degree value) of the fatty matter. Results reported hereby showed a low microbial load except for the yeasts and molds. The values found for the physico-chemical factors (low for the $\mathrm{pH}$ and the aw and high for the ADV and salt content) would suggest an inhibitory effect on the initial microflora charge of the black table olives.

KEY-WORDS: Microflora - Morocco - Physico-chemical properties Table black olive.

\section{INTRODUCTION}

Besides some fresh fruits, vegetables are less involved in food poisoning outbreaks. The potential hazards exist when those products are hand-manipulated by carrier people and consummed directly like the black table olives in Morocco.
Black table olives are harvested when fully matured and completely dark by hand or by knocking the fruits from the tree with a slendor pole or by shaking the branches and collecting the fruits from the ground. Contamination of the fruits by hazardous microorganisms may occur while falling unavoidably on the ground or by workers while harvesting handling and working the fruits.

The harvested olives are filled in bags and salted (solid salt is sprinkled on the fruits while filling them in the bags). The bags are then empiled one on the other and a heavy object (stone) in deposited on the top bag. The bitter liquid is exuded under the effect of the mecanic action of bags weight and the stone put on them. This operation is aided by salt.

The traditional procedure used in Morocco consists of a solid salting which lead to a dry product because of the severe water loss. This makes the fruits to soften (drysalting olives). In the present study 11 bulcks of the black table olives made traditionally were evaluated for their physico-chemical and microbiological characteristics.

\section{MATERIAL AND METHODS}

\section{Samples collection}

Samples were taken from the retail market. 11 bulcks of black olives of the variety picholine (Moroccan) at different sellers from two Moroccan cities Rabat and Marrakech were sampled.

\section{Physico-chemical methods}

\section{pH}

$\mathrm{pH}$ values were determined by the use of a $\mathrm{pH}$-meter type WTW pH-521. $20 \mathrm{~g}$ of the sample were blended by a wareing type blender in $50 \mathrm{ml}$ of distilled water until obtaining a fluid slurry.

\section{aw}

Water activity of samples was determined by the mean of a hygroscopic apparatus type Rotronic DT (Switzerland) at $25,5 \pm 1^{\circ} \mathrm{C}$ 


\section{ADV (Acid Degree Value)}

Acid Degree Values of the fat extracted from olives were determined by titrating measured portions with alcoholic $\mathrm{N} / 100 \mathrm{NaOH}$ using thymol blue as a $\mathrm{pH}$ indicator. The fatty portion was extracted by hexan in a separatory funnel.

\section{Sodium chloride}

The sodium chloride level in samples was determined on the same slurry prepared for the $\mathrm{pH}$ determination. 10 $\mathrm{ml}$ of the aqueous portion were diluted to $1 / 100$ in distilled water and titrated by a N/100 silver nitrate solution in presence of potassium chromate.

\section{Microbiological methods}

Ten $\mathrm{g}$ of each sample were blended with $90 \mathrm{ml}$ of distilled water in a wareing type blender. The homogenous mixture was used as mother dilution for making serial dilutions for further microbiological determinations.

\section{SPC: Standard plate count}

Appropriate serial dilutions were pour plated on trypticase soya agar (TSA). Plates were incubated at $30^{\circ} \mathrm{C}$ for 3 days. The CFUs were evaluated.

\section{Coliform counts}

* Fecal coliforms

The MPN (most probable number) using 3 tubes per dilution was determined on brilliant green bile broth with Durham's tubes, and incubation was done at $44^{\circ} \mathrm{C}$, for 24 hours. Tubes that had presented trouble and gas were inoculated on tryptone water and incubated at $44^{\circ} \mathrm{C}$ for 24 hours. Indole production was revealed by Kovac's reagent addition.

* Total coliforms

Dilutions $\left(10^{-1}\right.$ to $\left.10^{-3}\right)$ were pour plated on deoxycholate agar. Plates were incubated at $36^{\circ} \mathrm{C}$, for 24 hours. Red colonies were counted as coliforms.

\section{Staphylococci}

The enrichment was done on nutrient broth using 3 tubes per dilution. Tubes showing a trouble after 24 hours incubation at $36^{\circ} \mathrm{C}$ were streaked on Mannitol-Salt-Agar. The yellow colonies appeared on this medium were checked for Gram and catalase reactions.

\section{Enterococci}

Enterococci were pour plated directly on KFStreptococci agar. Plates were placed at $36^{\circ} \mathrm{C}$ for 48 hours. The grown colonies on this medium were Gram stained and checked for catalase reaction.

\section{Salmonella}

$25 \mathrm{~g}$ of the sample were added to $225 \mathrm{ml}$ of sterile peptone water and incubated for 18 hours at $37^{\circ} \mathrm{C}$. For the following the method described by Poelma and Silliker (8) was used.

\section{Spore forming bacteria}

The mother dilution was heated at $80^{\circ} \mathrm{C}$ for $10 \mathrm{~min}$ and immediately cooled in iced water.

\section{* Clostridium}

Anaerobic sulfite reducers clostridia were grown on Reinforced Clostridium medium in tubes. Just after inoculation and when the medium was still liquid, $0,1 \mathrm{ml}$ of ferrous solution and $0,1 \mathrm{ml}$ of Sodium Sulfite solution were added. Tubes were then inoculated by 2,1 and 0,1 $\mathrm{ml}$ of the heated dilution, shaked and incubated at $30^{\circ} \mathrm{C}$ for 24 to 48 hours.

* Bacillus

Aerobic spore forming bacteria were surface plated on TSA. The plates were incubated at $30^{\circ} \mathrm{C}$. Colonies were counted after 48 hours.

\section{Yeasts and Molds}

A surface plating procedure on Potato-Dextrose-Agar and Malt agar was used. The plates were incubated at $27^{\circ} \mathrm{C}$. Yeasts and Molds colonies were counted on the same medium respectively after 4 and 7 days.

\section{RESULTS AND DISCUSSIONS}

The physico-chemical parameters of black table olive samples are presented in table 1 . The aw ranged from 0,7 to 0,9 indicating a wide variation among the samples. The same pattern is observed in the $\mathrm{NaCl}$ concentration which range from 3,47 to 10,18 as well as for the $\operatorname{ADV}(0,83$ to 4,59 ). Black olives are prepared by a traditional procedure which may vary from one procedure to another. It is known that those factors play a potent effect on the growth of microorganisms (2). Low aw and the presence of Free Fatty Acids (ADV) and a high concentration of $\mathrm{NaCl}$ in the product may inhibit the initially contaminating flora. Standards for black olives are not defined since their technology is still traditional.

Table I

Physico-chemical characteristics of the black table olive samples.

\begin{tabular}{ccrcl}
\hline Samples & pH & $\mathrm{NaCl}$ & ADV & aw \\
\hline 1 & 5,36 & 4,62 & 4,41 & 0,83 \\
2 & 4,97 & 8,42 & 1,37 & 0,70 \\
3 & 6,15 & 4,68 & 1,88 & 0,90 \\
4 & 4,86 & 4,86 & 3,80 & 0,82 \\
5 & 5,61 & 8,60 & 3,01 & 0,82 \\
6 & 4,90 & 10,18 & 4,59 & - \\
7 & - & 4,70 & 1,65 & 0,85 \\
8 & - & 7,26 & 0,86 & 0,79 \\
9 & 5,87 & 6,36 & 3,33 & 0,82 \\
10 & 5,37 & 3,47 & 0,83 & 0,75 \\
11 & 6,33 & 5,97 & 0,90 & - \\
\hline
\end{tabular}

Legends

$\mathrm{NaCl}$ in \%

$\mathrm{ADV}$ in $\mathrm{mg} \mathrm{KOH} / \mathrm{g}$ Fat 
The low values of aw found in the present study (table 1) are most probably related to drying and salting. Salting may lead to a severe water loss under the effect of osmosis due to the high salt concentration and also to the mecanic action (empiling bags and the heavy device deposited on them) so the weight may help in water exudation by the fruits. The aw values we found are lower than the average aw reported by Marsilio and Spotti (6) for the italian black olives.

The acidic $\mathrm{pH}$ even slight (table I) are most probably caused by the double action of (a) the lipolytic microorganisms and/or lipases which may release Free Fatty Acids (FFA) and (b) the lactic acid bacteria. This can be supported by the high ADV which may tell about the level of the lipolysis. This may constitute a possible factor for preserving the olive fruits against the most frequent spoilage due to Bacillus and/or Clostridium.

The ADVs are related to the lipolytic action of some microorganisms. The FFA level is relatively high with regard to the fatty portion of the product. Those compounds are active inhibitors against most microorganisms (1), (3), (4).

The microbial count patterns reported in table II showed low levels of the microorganisms enumerated. Those results were expected because of the product environmental conditions. The low aw, acidic $\mathrm{pH}$, high salt content and the high FFA level may have an ample action on the initial microflora of the black olives. The low microbial load could be due to the occurrence of some natural inhibitors in the olives such as the polyphenols (9).

Table II

Microbiological profiles of the morrocan black table olive samples. Figures are in $\mathrm{CFU} / \mathrm{g}$

\begin{tabular}{|c|c|c|c|c|c|c|c|c|c|}
\hline Samp. & $\begin{array}{l}\text { SPC } \\
10^{4}\end{array}$ & $\begin{array}{c}\text { TC } \\
10^{2}\end{array}$ & $\begin{array}{l}\text { FC } \\
-\end{array}$ & $\begin{array}{c}\text { SAL } \\
-\end{array}$ & $\begin{array}{l}\text { ENT } \\
10^{2}\end{array}$ & $\begin{array}{c}\text { STAPH } \\
-\end{array}$ & $\begin{array}{c}\text { ANSP } \\
-\end{array}$ & $\begin{array}{l}\text { ASP } \\
10^{2}\end{array}$ & $\begin{array}{l}Y+M \\
10^{5}\end{array}$ \\
\hline 1 & 56 & 4 & 15 & - & 7 & 64 & 2 & - & 6,5 \\
\hline 2 & 8 & - & - & - & 2 & - & - & - & 7 \\
\hline 3 & 258 & - & - & - & 20 & - & - & - & 23 \\
\hline 4 & 790 & - & - & - & - & 3 & - & 5 & 76 \\
\hline 5 & 51 & - & - & - & - & - & - & - & 3,6 \\
\hline 6 & 6 & - & - & - & - & - & 10 & - & 0,5 \\
\hline 7 & 380 & - & - & - & - & - & - & 2,6 & 20 \\
\hline 8 & 35 & - & - & - & - & 4 & - & 50 & 2 \\
\hline 9 & 3,3 & 320 & - & - & 1 & 20 & - & - & 3 \\
\hline 10 & 230 & 15 & - & - & 16 & 11 & - & - & 4,0 \\
\hline 11 & 4,4 & - & - & - & 12 & 4 & - & 30 & 0,5 \\
\hline SD & 232 & 91 & 4 & - & 7 & 18 & 2 & 15 & 21 \\
\hline
\end{tabular}

Legends

SPC : Standard plate count

T/F C : Total/fecal coliforms.

SAL : Salmonella.

ENT : Enterococcus.

STAPH : Staphylococcus.

ANANSP : Aerobic Anaerobic sporeforming bacteria

$\mathrm{Y}+\mathrm{M} \quad$ : Yeast and Molds

It should be emphasized here that yeasts and molds were present in high numbers relatively to the other groups of microorganisms. So the formers are known to be more resistant to high salt concentration and can grow in low aw environment (6). This is in agreement with the result reported by Tantaoui-Elaraki et al (10) about the microflora of Moroccan black olives. Molds are potential hazardous microorganisms and their presence is related to mycotoxins formation (5), (11).

Salting of the product may render the environment less suitable for microorganisms by lowering the aw. The FFA release by lipolytic microorganisms present in/on the olives fruits may also enhance the inhibitory effect for those factors. Hence the inhibition of the fastidious microorganisms would be achieved by the action of various inhibitory factors including $\mathrm{pH}$, aw, salt, FFA and others not studied in the present work and related to the presence of some polyphenols in black olive fruits (7).

Upon the foregoing the black table olives are preserved from spoilage by Bacillus and/or Clostridium and other undesirable microorganisms by the occurrence of the antimicrobial factors including mainly low aw, acidic $\mathrm{pH}$, high salt content and high FFA levels as well as other chemicals occurring naturally in olives. These factors are also inhibitory for the hazardous bacteria. However the growth of molds seem not stopped.

The salting-drying process applied to black table olives may not prevent molds growth and consequently subsequent amount of mycotoxins may render the safety of the product made by the traditional procedure doubtful. Our 
finding could be exploited to control the process by preventing molds growth prior to salting or during drying and storing.

\section{REFERENCES}

1. Altenbern, R.A.- "Effect of exogenous fatty acids on growth and enterotoxin B formation by Staphylococcus aureus 14458 and its membrane mutant".- Can. J. Microbial 23 (1977) 389-397.

2. Faid, M.; Larpent, J.P.; Larpent, M.; Chabard, J.L. and Berger, J.A."Antimicrobial factors in traditional Moroccan smen: aw, $\mathrm{pH}$, Acidity and Free Fatty Acids".- Sci. Aliment. 10 (1990) 659-670.

3. Fay, J.P. and Farias, R.N.- "The inhibitory action of fatty acids on the growth of Escherichia coli".- J.G. Microbial. 91 (1975) 233-240.

4. Freese, E.; Sheu, C.W. and Galliers, E.- "Function of lipophylic acids as antimicrobial food additives".- Nature 241 (1973) 321-335.

5. Gracián, J. y Arévalo, G.- "Presencia de aflatoxinas en los productos del olivar".- Grasas y Aceites 31 (1980) 167-171.

6. Marsilio, V and Spotti, E.- "Indagine sull'inquinamento fungino di olive nere da essicate".- Industria Conserve 62 (1987) 287-291.

7. Nychas, G.J.E.; Tassou, S.C., e Board, R.G.- "Phenolic extract from olives: inhibition of Staphylococcus aureus".- Letters Appl. Microbiol. 10 (1990) 217-220

8. Poelma, P.L. and Silliker, J.H.- "Salmonella in Compendium of methods for the examination of foods.- (1976) ed M.L. Speck APHA publisher (Washington DC), 301-328.

9. Ruiz-Barba, J.L.; Ríos-Sánchez, R.M., Fedriani-Iriso, C., Olias, J.M. Ríos, J.L. and Jiménez-Diaz, R.- "Bactericidal effect of phenolic compounds from green olives on Lactobacillus plantarum".- Systematic Appl. Microbiol. 13 (1990) 199-205.

10. Tantaoui-Elaraki, A.; Samane, S. and Roquebert, M.F.- "Mycroflora of Moroccan greek style black olives".- Microbiol. Alim. Nut. 8 (1990) 257-264.

11. Tantaoui-Elaraki, A., et Letutour, B.- "Contamination eventuelle des olives et derives par les mycotoxines: le point".- Oleagineux 40 (1985) $451-454$

(Recibido: Agosto 1991) 